
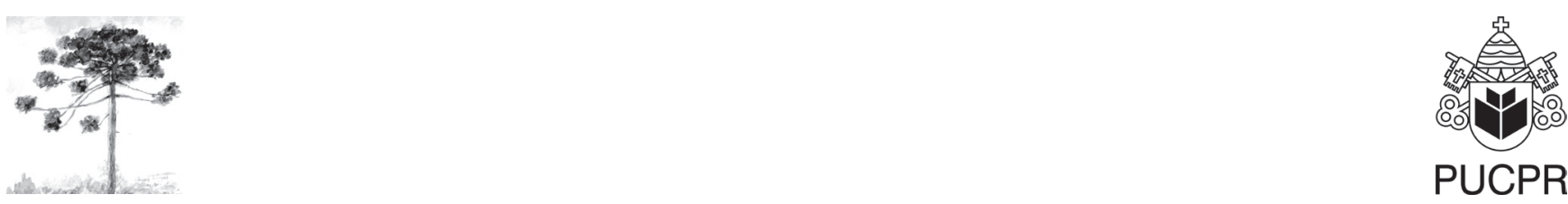

PUCPR

\title{
EFFECT OF CRUDE OIL ON THE DEVELOPMENT OF WHITE MANGROVE SEEDLINGS (Avicennia germinans) IN THE NIGER DELTA, NIGERIA
}

\author{
Efeito do petróleo sobre espécies de manguezais (Avicennia germinans) \\ no delta do Rio Niger, Nigéria
}

\footnotetext{
AC Chindah ${ }^{[a]}$, SA Braide ${ }^{[b]}$, JO Amakiri ${ }^{[c]}$, J Onokurhefe $^{[\mathrm{d}]}$

${ }^{[a]}$ Institute of Pollution Studies Rivers State University of Science and Technology, Nkpolu Oroworukwo P M B 5080, Port Harcourt Rivers State - Nigeria, e-mail: alexchindah@hotmail.com

[b] Institute of Pollution Studies Rivers State University of Science and Technology, Nkpolu Oroworukwo P M B 5080, Port Harcourt Rivers State - Nigeria.

[c] Plant Science and Biotechnology University of Port Harcourt Choba, Rivers State - Nigeria.

[b] Institute of Pollution Studies Rivers State University of Science and Technology, Nkpolu Oroworukwo P M B 5080, Port Harcourt Rivers State - Nigeria.
}

\begin{abstract}
Crude oil is a complex hydrogen whose introduction into the may be hazardous to aquatic and human life, and consequently a threat to natural resources. The severity of the impact of crude oil depends on a variety of factors, including characteristics of the oil itself, natural conditions, such as water temperature and weather, and the sensitivities of receiving or biota. Consequently, various types of biological resources such as mangrove seedlings have different sensitivities to oil spills. The long term persistence of oil in the environment may cause defoliation and possibly death. Recruitment of seedlings into the oiled area may also be affected. This study is designed to evaluate the acute and chronic effects of crude oil (Bonny Light) on the growth performance of mangrove seedlings in a laboratory condition; monitoring critical plant growth attributes such as stem height and diameter, leaf length, width and numbers of leaves (leaf production), senescence and seedlings survival, for sixteen weeks. The study revealed that the mangrove seedlings responded differently in growth attributes with varying treatment. Evidence of crude oil effects were remarkably demonstrated between control and acute (Wilcoxon sign -rank t-test $(1.0)>\mathrm{P}(0.29)_{0.05}$ and chronic (Wilcoxon sign - rank, t-test $(1.0)>\mathrm{p}(0.47)_{0.0 .}$. The mangrove critical growth responses by mangrove seedlings as a result of the treatments were further explained by the cluster and correspondence analyses.
\end{abstract}

Keywords: Avicennia germinans. Mangrove seedling. Crude oil. Niger Delta. Nigeria. 


\section{Resumo}

O petróleo é um hidrocarboneto complexo, cuja contaminação no meio aquático é perigosa para o ser humano e, consequentemente, danosa para as fontes de recursos naturais. A severidade do impacto depende de diferentes fatores, tais como a composição do próprio petróleo, condições naturais (como condições climáticas, temperatura da água, pH, salinidade, entre outros). Nesse contexto, considerando os manguezais, diferentes plantas estão sendo afetadas pela exposição de longa data a esse contaminante, principalmente as plantas jovens, muito sensíveis a esse fenômeno. O objetivo deste estudo foi avaliar os efeitos agudos e crônicos do petróleo (leve) sobre o crescimento, em laboratório, de mudas de plantas do mangue. Foram monitorados, durante seis semanas, diferentes parâmetros do vegetal, como o crescimento da planta, a altura e o diâmetro do caule, o comprimento das folhas, o formato e o número de folhas, a senescência e sobrevivência dos exemplares. O estudo revelou que as plantas jovens foram afetadas no seu crescimento durante o tratamento com o hidrocarboneto. Esse fato foi confirmado estatisticamente ao comparar-se o grupo controle com o grupo que recebeu a dosagem aguda (Wilcoxon - teste $t(1,0)>p(0,29)_{0,05}$ e o grupo controle comparado com o tratamento crônico (Wilcoxon - teste $t(1,0)>p(0,47)_{0,05}$. Portanto, ocorre um prejuízo em todo o manguezal da região do delta do Níger, fenômeno observado ao estudar-se as plantas jovens, mais suscetíveis à contaminação pelo petróleo.

Palavras-chave: Avicennia germinans. Manguezais. Petróleo. Delta do Rio Níger. Nigéria.[\#]

\section{INTRODUCTION}

The Niger delta of Nigeria has four main ecological zones; coastal barrier islands, mangrove swamp forests, freshwater swamps, and lowland rainforests. These ecological zones are incredibly well-endowed with highest concentrations of biodiversity in addition to supporting the abundant flora and fauna $(1,2)$ In the lower delta, within the estuarine limits is located large area of mangrove forests estimated to cover approximately 5,000 $8,580 \mathrm{~km}^{2}$ of mangrove wetland (3). There are three main mangrove families; (Rhizophoraceae, Avicenniaceae and Combretaceae) comprising (six) 6 species namely: Rhizophora racemosa, Rhizophora mangle, Rhizophora harrisonii, Languncularia racemosa, Avicennia germinans and Conocarpus erectus and the exotic family Palmae (Arecaceae) Nypa fruticans van Wurmb that is now spreading fast across the Niger Delta (2-6).

The poor land management upstream from human impacts coupled with oil industrial activities and associated pollution of oil has caused land take and mangrove forest clearing, severe fragmentation, and damage to the ecological zone ecosystem (1, 7-15). These scenarios have facilitated and provided avenue for a non-native invasive species of palm, Nypa fruticans that have quickly colonized the mangrove system. The shallow root system and poor litter generation potential help to destabilize the normal banks sediment distribution, resulting in declining nutrient processes, poor recruitment potentials, decreases in biodiversity and reducing of ecosystem functions.

The scenario in the ecosystem is responsible for poor utility value of highly important resources derived from the indigenous people whose livelihoods depend largely on, such as logs, fuel wood, charcoal, wood-chips, paper pulp, scaffold poles, piling and construction material, stakes for fish traps and fishing platforms, railway sleepers, wood for furniture making and carvings, material for roof thatching, bark for tannin, medicinal products, sugar, alcohol, acetic acid, dye and poor yield of other non tree species including fin and non fin fishes. In addition, natural regeneration potentials of mangrove species after such ecological abuse is poor $(14,16)$. These circumstances generated apprehension and great concern among various stakeholders, thus the demand to re-vegetate the degraded mangrove areas. In order to achieve this therefore, we evaluated the development of mangrove seedling under different crude oil conditions, using a hardy mangrove species Avicennia germinans that possesses pneumatophores which allow its roots to breathe even when submerged and expels absorbed salt from its leathery leaves (6). 


\section{MATERIALS AND METHODS}

\section{Description of study area}

The study was conducted at Eagle Island near Rivers State University of Science and Technology, Port Harcourt, located at the upper reach of Bonny estuary of the eastern Niger Delta, Nigeria and lies within longitude $4^{\circ} 35^{\prime \prime}-4^{\circ} .5 \mathrm{~N}^{\prime \prime}$ and latitude $7^{\circ} .00^{\prime \prime}-7^{\circ} .53^{\prime \prime} \mathrm{E}$ (Figure 1).

The area being predominanted by mangrove tress have other on tree plant species such as the fern (Achrostichum aureum), and grass (Paspalum varginatum) and animals, Periophthalmus papilo (mud skipper), Uca tangeri (fidder crabs) and Tympanotonus fuscatus (Periwinkles). These species amongst others contribution significantly to the dynamics and ecosystem function provided by the entire community.
The climate of the area is basically that of equatorial tropical rainfall occurring almost through the year except the mouths of December,January and February, which are not completely free from rainfall in some years. The annual rainfall of the area is about $2,405.2 \mathrm{~mm}$ (11). Annual mean air temperature is $31.3{ }^{\circ} \mathrm{C}$ the highest monthly mean temperature was $29.7^{\circ} \mathrm{C}$ (in August), and the lowest monthly mean temperature is $27.5{ }^{\circ} \mathrm{C}$ (in January). The surface seawater temperature values range between $25.9^{\circ} \mathrm{C}$ and $30.6^{\circ} \mathrm{C}$, and the salinity of the seawater ranges between $8 \%$ and $20 \%$. The tidal variations range between $0.43 \mathrm{~m}$ and $1.67 \mathrm{~m}$ with a mean tidal variation of $0.9 \mathrm{~m}$. The current flows are unidirectional flooding (inundation) during high tide and receding at low tide regime. The mud (sediment) has a dark appearance with hydrogen sulphide as the major by product of sulphur bacteria. The soil type is clay (Chikoko). Economic activities by human in this area are mainly, fishing, trading and transportation $(5,17)$.

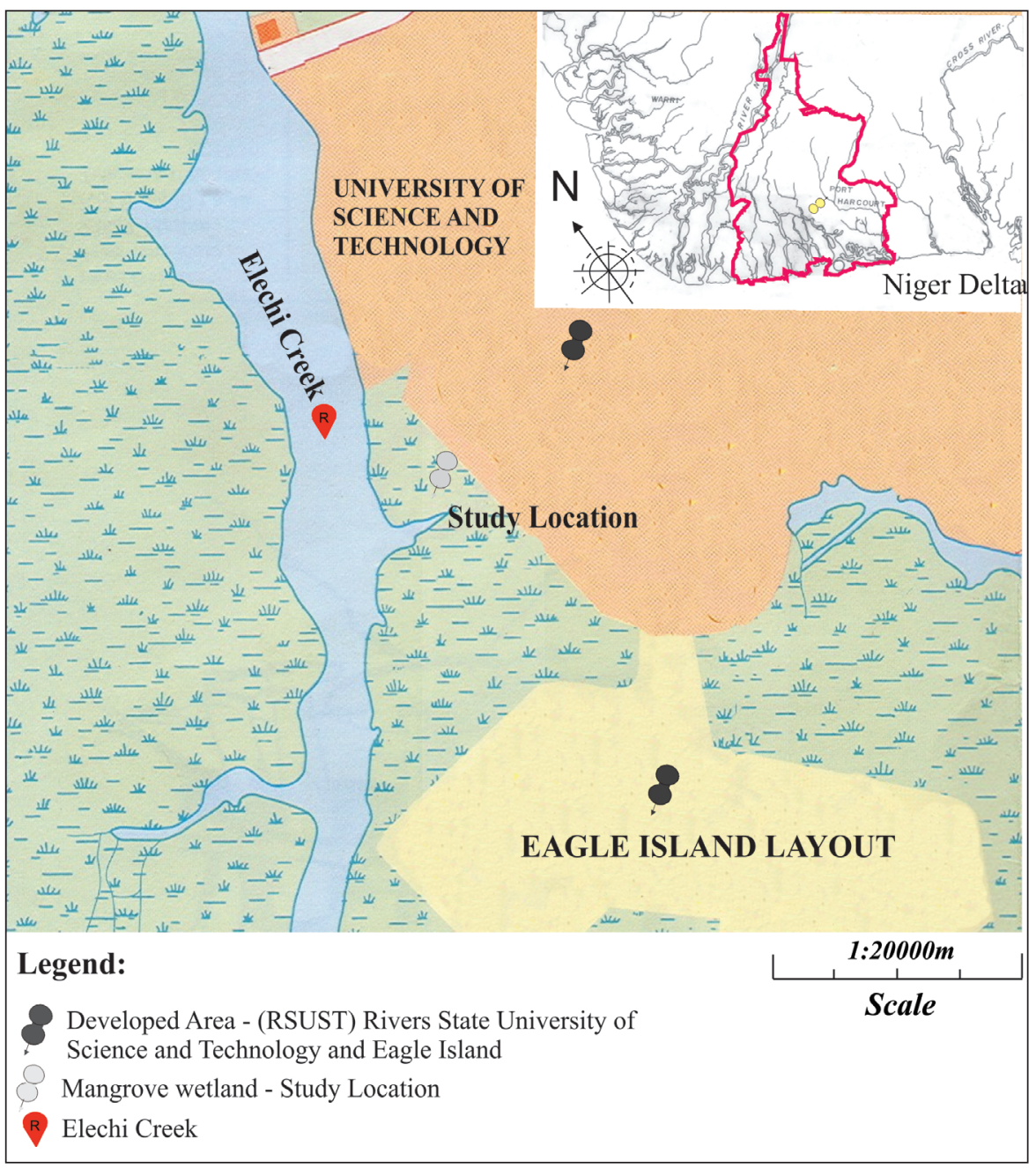

FIGURE 1 - Port Harcourt localization map, Nigeria, Africa 


\section{NURSERY PREPARATION}

The sampling sites were established in a relatively undisturbed tidal inundated mangrove wetland, beside the Rivers State University of Science and Technology, Port Harcourt was chosen after an investigation of the whole mangrove area (10 by $15 \mathrm{~m}^{2}$ ).

Surface soil form the study area was collected $(0-15 \mathrm{~cm})$ during low tide. The wet surface soil samples $(4 \mathrm{~kg})$ were weighed and potted in polyethylene bags $(40 \times 50 \mathrm{~cm})$, leaving $10 \mathrm{~cm}$ at the upper end for irrigation of water. Each bag was properly labeled.

The matured mangrove seedlings (Avicenna) in good conditions that tend to settle down in the substrate were carefully uprooted using hand trowel and transplanted into the potted bags ensuring that the there was no root damage. This was allowed to stabilize for 60 days ( 2 months) to eliminate possible effect of shock. The seedlings were arranged in 10 rows of parallel triplicates at $1 \mathrm{~m}$ intervals for each treatment (chronic, acute and control).

\section{TREATMENTS}

The seedlings were subjected to acute and chronic treatment of crude oil (Bonny Light) using indicative growth parameters such as stem growth, leaf production and growth and leaf drop - Senescence, and seedlings survival as surrogates.

Treatment commenced after stabilization period of 60 days.

For acute effect, a one-time treatment of crude oil of $120 \mathrm{~mL}$ was added at the base of the seedlings on the surface of the mud sample for chronic effect, smaller aliquot of $15 \mathrm{~mL}$ (crude oil) was added weekly. The crude oil for each treatment was delivered after measuring in a graduated cylinder which was allowed to drain for at least for 1 minute.

Shoot height, diameter of stem at the first inter-node, number of nodes, number of leaves, and leaf area, were measured individually using veneer caliper and the fate and growth of seedlings were monitored for 16 weeks.

Data analyses on seedling growth rate were for height, diameter, leaf length, and width, number of leaves, yellowing of leaves, and seedling survival for 16 weeks.
The calculation for RGR was adapted from Hunt (18), classical approach:

Where, $\mathrm{L}_{1}$ and $\mathrm{L}_{2}$ is the growth at time $\mathrm{t}_{1}$ and $t_{2}$, respectively.

$$
\frac{\mathrm{RGR}=\operatorname{In}\left(\mathrm{L}_{2}-\operatorname{In}\left(\mathrm{L}_{1}\right)\right.}{\mathrm{T} 2-\mathrm{T} 1}
$$

The response patterns of mangrove seedlings among treatments were examined by hierarchical cluster analysis on $\log (\mathrm{x}+1)$ transformed data using JMP IN analytical software (16, 20, 21). Group average sorting $=$ unweighted pair-group method (19) was used as the clustering method and Bray-Curtis similarity (22) for resemblance measure (22).

Results were expressed as a dendogram in which samples were ordered into groups. Correspondence analyses on growth responses were carried out using Kovach Computing ServicesMultiVariate Statistical Package (MVSP) version 3.1.

\section{RESULTS}

\section{Chronic treatment}

The response of seedling for chronic exposure in respect of stem growth (height) indicated a steady growth for both control and treatment plants. Initial growth $(184 \mathrm{~mm})$ was more rapid for the chronic treatment seedlings to the $10^{\text {th }}$ week $(327.5 \mathrm{~mm})$, thereafter, the growth continued but very gradually to the end of the $16^{\text {th }}$ week $(350.5$ $\mathrm{mm}$ ). The seedling under control condition rapidly continued to grow to the while the treatment seedlings growth relatively stagnated from the $12^{\text {th }}$ week to the end of the study (16 ${ }^{\text {th }}$ week). However the control $\left(\mathrm{R}^{2}=0.92\right)$ relatively recorded high regression value than the treatment $\left(R^{2}=0.92\right)$ Table 1 and Figure 2 .

Similar growth trend was observed for the stem diameter with increases being observed from week 0 to the $11^{\text {th }}$ week before growth stagnation was observed for the treatment plant to the end of the experiment while the control relatively continued growth to the end of the experiment but no difference was observed in the regression values between the control $\left(\mathrm{R}^{2}=0.93\right)$ and treatment $\left(\mathrm{R}^{2}=0.93\right)$ Table 1 and Figure 2.

Leaf length for the treatment plant tended to decline almost steadily with pulses at the $2^{\text {nd }}(46.12$ $\mathrm{mm}), 8^{\text {th }}(37.44 \mathrm{~mm})$ and the $14^{\text {th }}$ week $(23.73 \mathrm{~mm})$. 
TABLE 1 - Regression equations for relationships for each treatment on Avicennia germinans seedling growth characteristics

\begin{tabular}{|c|c|c|c|}
\hline \multirow{2}{*}{ Attributes } & Treatment & Model relationship & $\mathrm{R}^{2}=$ \\
\hline & Chronic & $y=$ & \\
\hline \multirow[t]{2}{*}{ Stem height } & Control & $14.265 x+154.73$ & 0.986 \\
\hline & Treatment & $10.079 x+203.66$ & 0.922 \\
\hline \multirow[t]{2}{*}{ Stem diameter } & Control & $0.1506 x+2.8092$ & 0.936 \\
\hline & Treatment & $0.1506 x+2.8092$ & 0.936 \\
\hline \multirow[t]{2}{*}{ Leaf length } & Control & $-1.6384 x+46.239$ & 0.854 \\
\hline & Treatment & $-1.6384 x+46.239$ & 0.854 \\
\hline \multirow[t]{2}{*}{ Leaf width } & Control & $-0.5118 x+14.924$ & 0.614 \\
\hline & Treatment & $-0.5118 x+14.924$ & 0.614 \\
\hline \multirow[t]{2}{*}{ Leaf senescence } & Control & $4.7843 x-22.529$ & 0.775 \\
\hline & Treatment & $4.7843 x-22.529$ & 0.775 \\
\hline \multirow[t]{2}{*}{ Seedling survival } & Control & $-0.152 x+10.838$ & 0.517 \\
\hline & Treatment & $-0.152 x+10.838$ & 0.517 \\
\hline \multirow[t]{2}{*}{ Leaf production } & Control & $-0.1277 x+9.5199$ & 0.053 \\
\hline & Treatment & $-0.1277 x+9.5199$ & 0.053 \\
\hline & Acute & & \\
\hline \multirow[t]{2}{*}{ Stem height } & Control & $y=14.265 x+154.73$ & $\mathrm{R} 2=0.9857$ \\
\hline & Treatment & $y=5.6757 x+214.6$ & $\mathrm{R} 2=0.8827$ \\
\hline \multirow[t]{2}{*}{ Stem diameter } & Control & $y=0.1945 x+2.1673$ & $\mathrm{R} 2=0.9547$ \\
\hline & Treatment & $y=0.0531 x+3.4077$ & $\mathrm{R} 2=0.8778$ \\
\hline \multirow[t]{2}{*}{ Leaf length } & Control & $y=1.9881 x+39.169$ & $\mathrm{R} 2=0.9573$ \\
\hline & Treatment & $y=-1.6384 x+46.239$ & $\mathrm{R} 2=0.854$ \\
\hline \multirow[t]{2}{*}{ Leaf width } & Control & $y=0.3352 x+17.015$ & $\mathrm{R} 2=0.7271$ \\
\hline & Treatment & $=-0.5118 x+14.924$ & $\mathrm{R} 2=0.6137$ \\
\hline \multirow[t]{2}{*}{ Leaf senescence } & Control & $y=1.6422 x-5.9559$ & $\mathrm{R} 2=0.8898$ \\
\hline & Treatment & $y=4.2206 x-3.2794$ & $\mathrm{R} 2=0.9678$ \\
\hline \multirow[t]{2}{*}{ Seedling survival } & Control & $y=10$ & $\mathrm{R} 2=\# \mathrm{~N} / \mathrm{A}$ \\
\hline & Treatment & $y=-0.4559 x+9.9853$ & $\mathrm{R} 2=0.8854$ \\
\hline \multirow[t]{2}{*}{ Leaf production } & Control & $y=0.5892 x+5.1088$ & $\mathrm{R} 2=0.881$ \\
\hline & Treatment & $y=-0.3135 x+7.2096$ & $\mathrm{R} 2=0.8781$ \\
\hline
\end{tabular}

While the control seedlings had almost an exponential growth trend from start $(40.4 \mathrm{~mm})$ to finish $(69.1$ $\mathrm{mm})$ and there was no differences in the regression values for the control $\left(\mathrm{R}^{2}=0.85\right)$ and treatment $\left(\mathrm{R}^{2}\right.$ $=0.85)$ Table 1 and Figure 2.

Senescence in seedlings for the control commenced from the $3^{\text {rd }}$ week and continued uniformly to the $7^{\text {th }}$ week before an increase from the $8^{\text {th }}$ week that continued exponentially to the $12^{\text {th }}$ week. It then maintained a steady value before a slight increase in the $16^{\text {th }}$ week. However, the treated seedlings started senescence from the $6^{\text {th }}$ week and increased exponentially to the end of the experiment $\left(16^{\text {th }}\right.$ week). Regression values for control $\left(\mathrm{R}^{2}\right.$ $=0.78)$ and treatment were the same $\left(\mathrm{R}^{2}=0.78\right)$ Table 1 and Figure 2.

The control seedlings had 100\% survival from start to the end of the experiment while in 


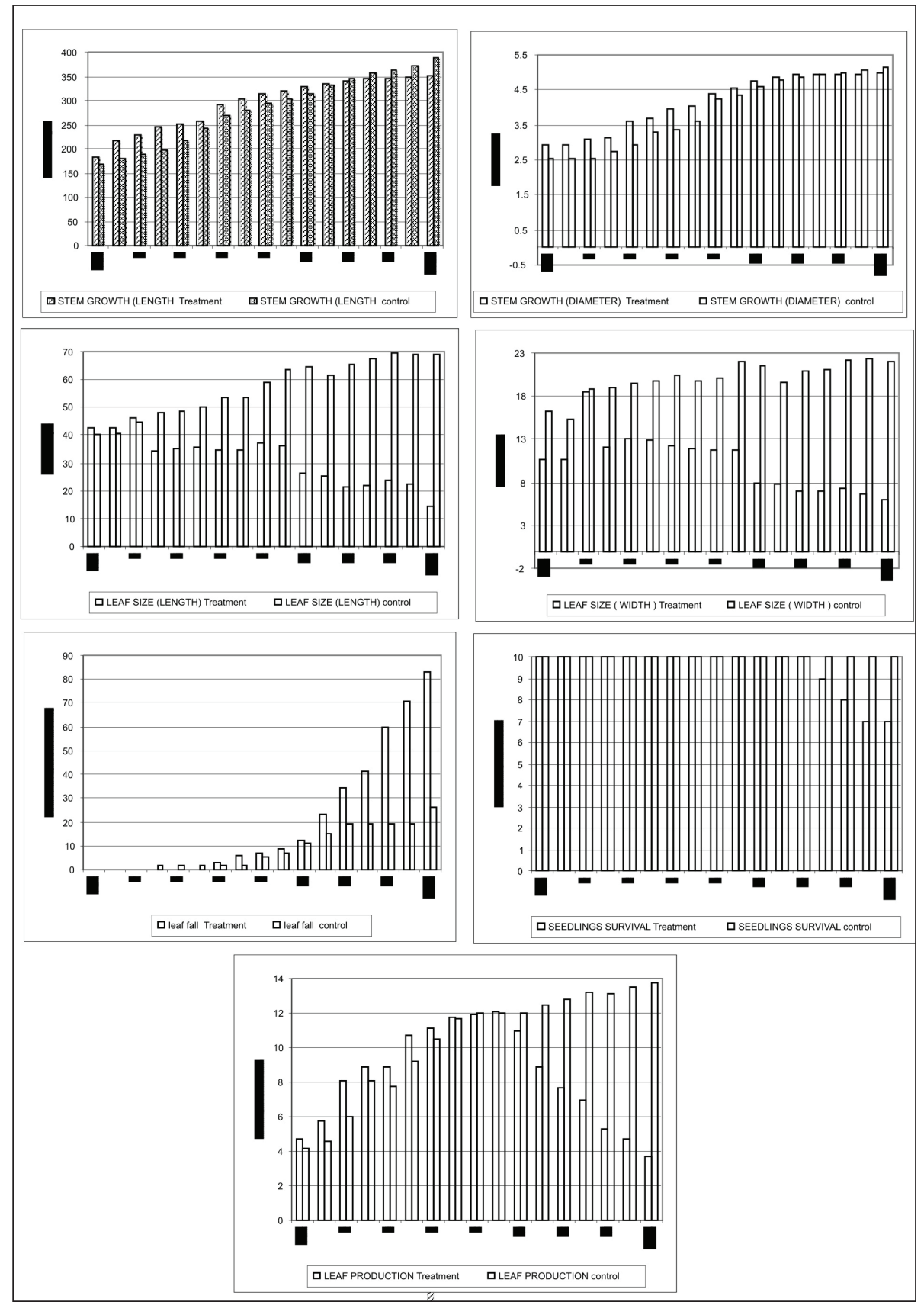

FIGURE 2 - The response ( $\mathrm{mm}$ ) of Avicennia germinans seedlings to control and chronic crude oil treatments

treated seedlings a reduction on survival commenced on the $13^{\text {th }}$ week but stabilized in the $15^{\text {th }}$ week.

\section{Acute treatment}

The mangrove seedlings subjected to acute treatment showed stem growth (height) in an exponential manner from start $(203.1 \mathrm{~mm})$ to the end of the experiment (week 16, $295 \mathrm{~mm}$ ) as was observed for the control and treatment from start $(169 \mathrm{~mm})$ to the end $(388 \mathrm{~mm})$ of study and the control was higher in magnitude $\left(\mathrm{R}^{2}=0.98\right)$ than that of the treatment seedlings $\left(\mathrm{R}^{2}=0.88\right)$. The observation for the stem diameter followed similar treat as observed for the stem height and recorded higher regression value for control $\left(\mathrm{R}^{2}=0.95\right)$ than the treated $\left(\mathrm{R}^{2}=0.88\right)$ Table 1 and Figure 3. 


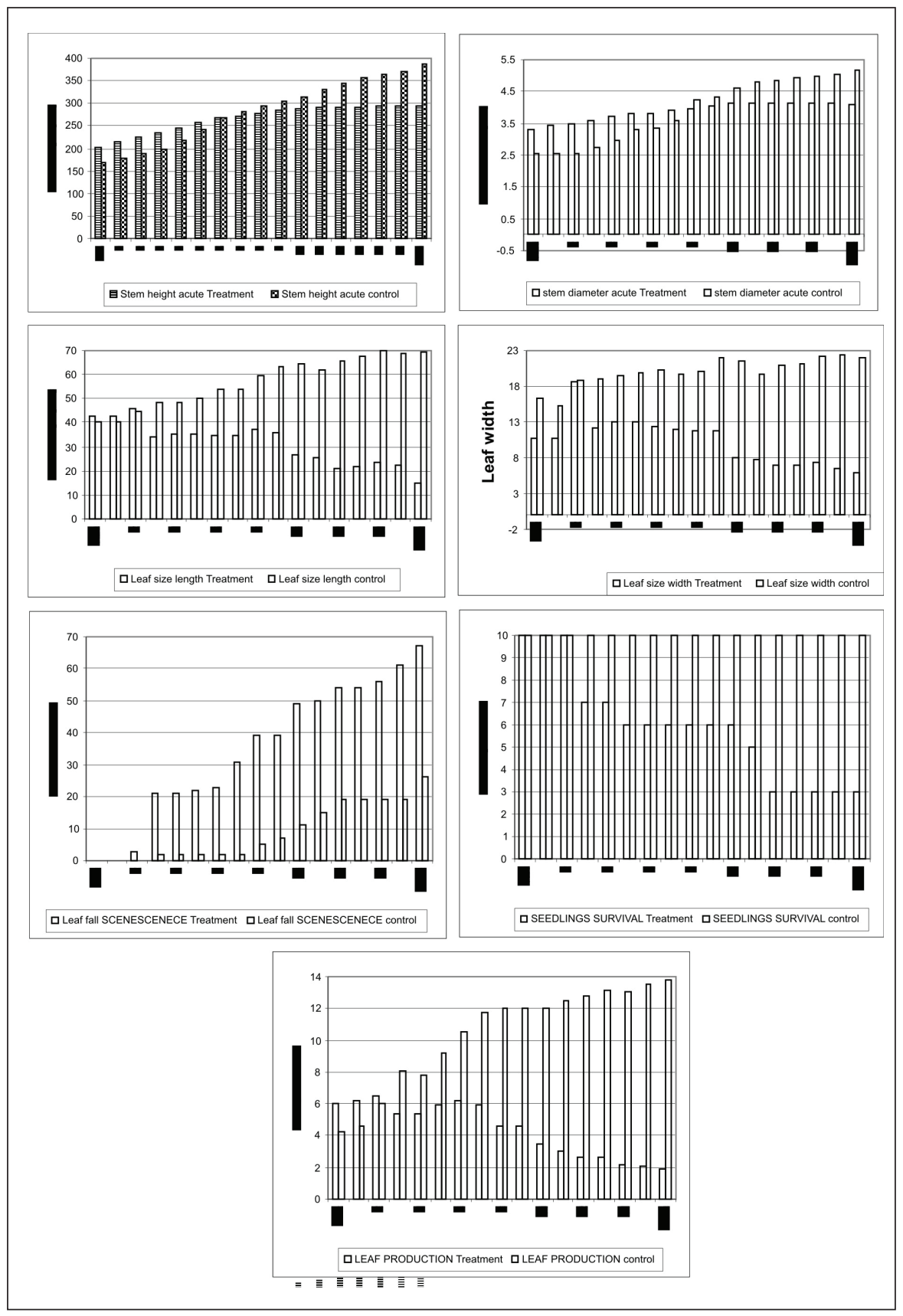

FIGURE 3 - The response of Avicennia germinans seedlings to control and acute crude oil treatments

leaf length seemingly increased from week $0(42.8 \mathrm{~mm})$ to the $2^{\text {nd }}$ week $(46.1 \mathrm{~mm})$ declined rapidly in the $3^{\text {rd }}$ week $(34.3 \mathrm{~mm})$ and maintained a consistent length from the $4^{\text {th }}$ week $(35.6 \mathrm{~mm})$ to the $7^{\text {th }}$ week $(35.6 \mathrm{~mm})$, and then increased slightly in the $8^{\text {th }}$ week $(37.4 \mathrm{~mm})$ declined slightly in the $9^{\text {th }}$ week $(36.2 \mathrm{~mm})$ and continued to the end of the study $\left(16^{\text {th }}\right.$ week $\left.-14.6 \mathrm{~mm}\right)$. While the control increased steadily to the end of the study with pulses at the
7 and $11^{\text {th }}$ week and had higher regression value $\left(\mathrm{R}^{2}=0.96\right)$ than the treatment $\left(\mathrm{R}^{2}=0.85\right)$. The observation on leaf width did not vary with that for the leaf length with control $\left(\mathrm{R}^{2}=0.73\right)$ having higher regression value than the treatment $\left(\mathrm{R}^{2}=\right.$ 0.61) Table 1 and Figure 3.

Leaf senescence commenced from the $2^{\text {nd }}$ week (3 leaves) for the treatment plants and sharply increased in the $3^{\text {rd }}$ week (21 leaves) and $5^{\text {th }}$ week 
(22 leaves) and then increased exponentially to the end of the experiment (67 leaves). In the control, leaf senescence commenced from the $3^{\text {rd }}$ week $(2$ leaves) and thereafter maintained a stable number to the $7^{\text {th }}$ week (2 leaves), with increase resumed in the $8^{\text {th }}$ week (5 leaves) to the $12^{\text {th }}$ week 19 leaves), stabilising again to the $15^{\text {th }}$ week (19 leaves) before a another leaf fall in the $16^{\text {th }}$ week (26 leaves). Contrary to the observed trend in stem height, stem diameter, leaf length and leaf width, the treated seedling had higher regression value $\left(\mathrm{R}^{2}=0.97\right)$ than the control $\left(\mathrm{R}^{2}=0.89\right)$ Table 1 and Figure 3.

Seedling survival for the treated plant showed 5 pulses with the first being in weeks $0-2^{\text {nd }}$ week with $100 \%$ survival, the second pulse was in between 3 and $4^{\text {th }}$ week $(70 \%)$, third pulse between $5^{\text {th }}$ week $(60 \%)$ to the $10^{\text {th }}$ week $(60 \%)$, fourth pulse at $11^{\text {th }}$ week $(50 \%)$, while the fifth pulse was between the $12^{\text {th }}$ week and $16^{\text {th }}$ week $(30 \%)$, while the control had 100\% survival throughout the duration of the study (Table 1 and figure 3).

The production for the treatment declined almost consistently from start (6 leaves) to the end of the study (1.9 leaves) in the contrary the control increased in leaf production to the end of the study (Table 1 and Figure 3).

The response of the seedling attributes for acute treatment demonstrated a declining pattern of stem height $-\mathrm{RGR}=5.64>$ Leaf fall $-\mathrm{RGR}=4.20$ $>$ leaf length - RGR $=2.48=$ leaf width - RGR $=1.67>$ stem diameter $-\mathrm{RGR}=1.36>$ seedling survival RGR $=0.86>$ leaf production $\mathrm{RGR}=$ 0.42 and chronic with stem height $-\mathrm{RGR}=5.83>$ leaf fall $-\mathrm{RGR}=4.42>$ leaf width $-\mathrm{RGR}=2.39$ $>$ seedling survival $-\mathrm{RGR}=1.85>$ leaf length $\mathrm{RGR}=1.46>$ Leaf production $-\mathrm{RGR}=1.23$. In the control, the pattern was stem height - RGR $=$ $5.22>$ leaf fall $-\mathrm{RGR}=3.26>$ leaf length $\mathrm{RGR}=$ $3.16>$ Leaf production $-\mathrm{RGR}=2.61>$ seedling survival - RGR $2.24>$ leaf width $-\mathrm{RGR}=2.16>$ Stem diameter $-\mathrm{RGR}=0.21$ (Table 2). However, the pooled data of all the seedling growth attributes using Wilcoxon sign -rank t-test for treatment comparison demonstrated non significance between acute and chronic (Wilcoxon sign -rank, t-test $(-7.0)<p$ $(0.85)_{0.05}$, but this was significant different between control and chronic (Wilcoxon sign -rank, t-test $(1.0)>\mathrm{p}(0.47)_{0.05}$ and between control and acute (Wilcoxon sign -rank, t-test $(1.0)>\mathrm{p}(0.29)_{0.05}$.

At each step, the two clusters that are closest together are combined into a single cluster. Similarity analysis using the average method and Euclidean distance measure for acute and chronic treatment examined responses of the plant attributes on the different exposure (Figures 4 and 5). The analyses revealed 3 major responses, denoted as $\mathrm{A}, \mathrm{B}$ and $\mathrm{C}$ of the attributes of the mangrove seedlings which yielded for the acute treatment, the highest affinity amongst the attributes was between stem diameter and leaf production (A-1, 99.5\%) and stem diameter and seedling survival (A-2, 99.1\%) followed by leaf length and yellowing of leaf (B, 92.3\%), and then stem height $(\mathrm{C}, 20 \%)$ in that decreasing response (Figure 4).

While the chronic treatment indicated strongest affinity between seedling survival and leaf production (A-1, 99.3\%) followed by seedling survival and leaf width (A-2, 99.0\%), stem diameter and leaf width (A-3, 98.2\%), stem diameter and leaf length $(\mathrm{B}, 91.6 \%)$ and stem height and stem diameter $(19.1 \%)$ in that decreasing order of response (Figure 5).

TABLE 2 - The relative growth rate (RGR) of Avicennia germinans seedlings exposed to different crude oil treatments

\begin{tabular}{lccc}
\hline Variables & Chronic & Acute & Control \\
\hline Leaf production & 1.23 & 0.42 & 2.61 \\
Seedlings survival & 1.85 & 0.86 & 2.24 \\
Stem height & 5.83 & 5.64 & 5.22 \\
Stem diameter & 1.57 & 1.36 & 0.21 \\
Leaf fallout & 4.42 & 4.20 & 3.26 \\
Leaf length & 1.46 & 2.48 & 3.16 \\
Leaf width & 2.39 & 1.67 & 2.16 \\
\hline
\end{tabular}


Effect of crude oil on the development of white mangrove seedlings

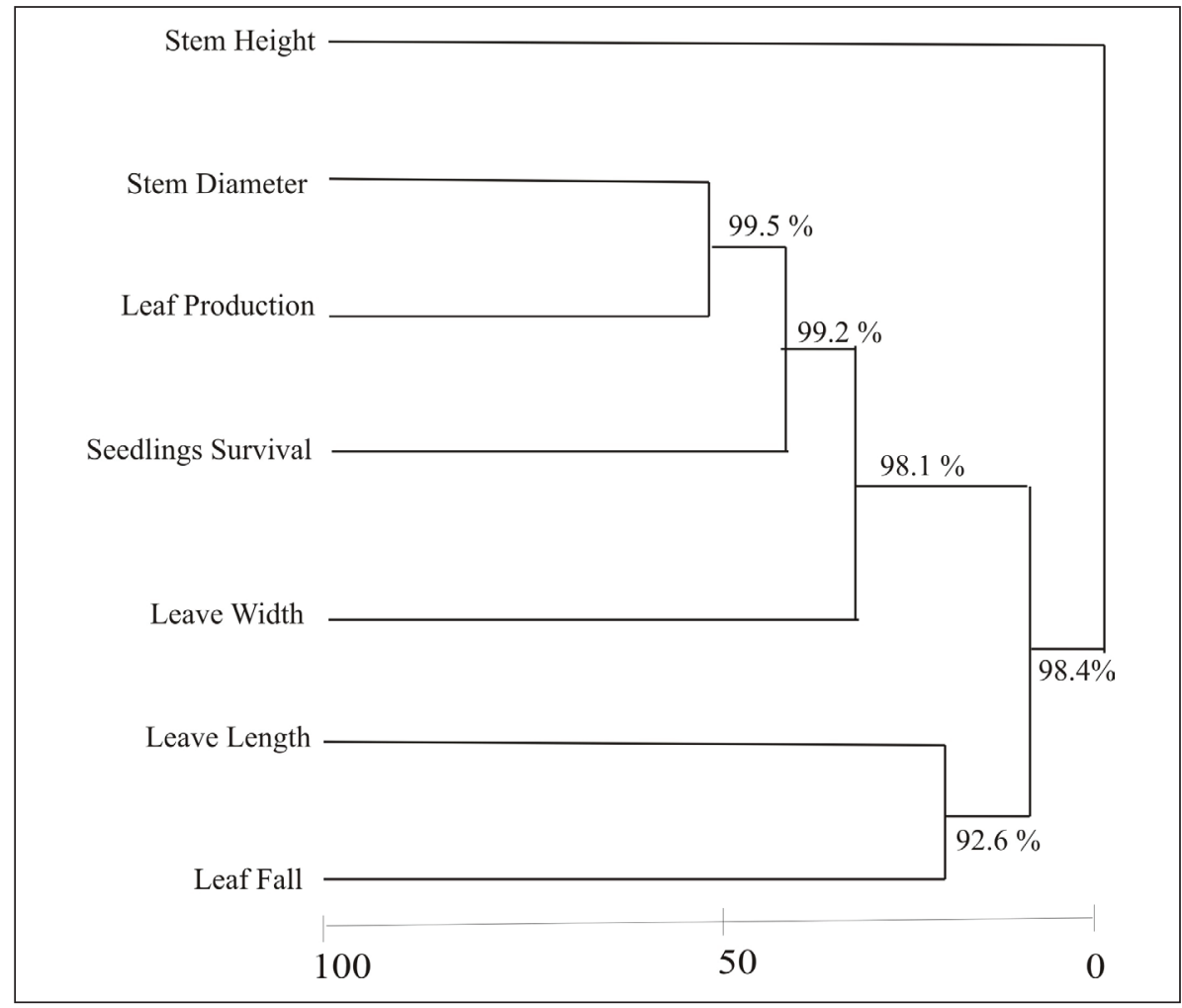

FIGURE 4 - The cluster analysis demonstrating association of growth attributes of seedlings exposed to acute treatment

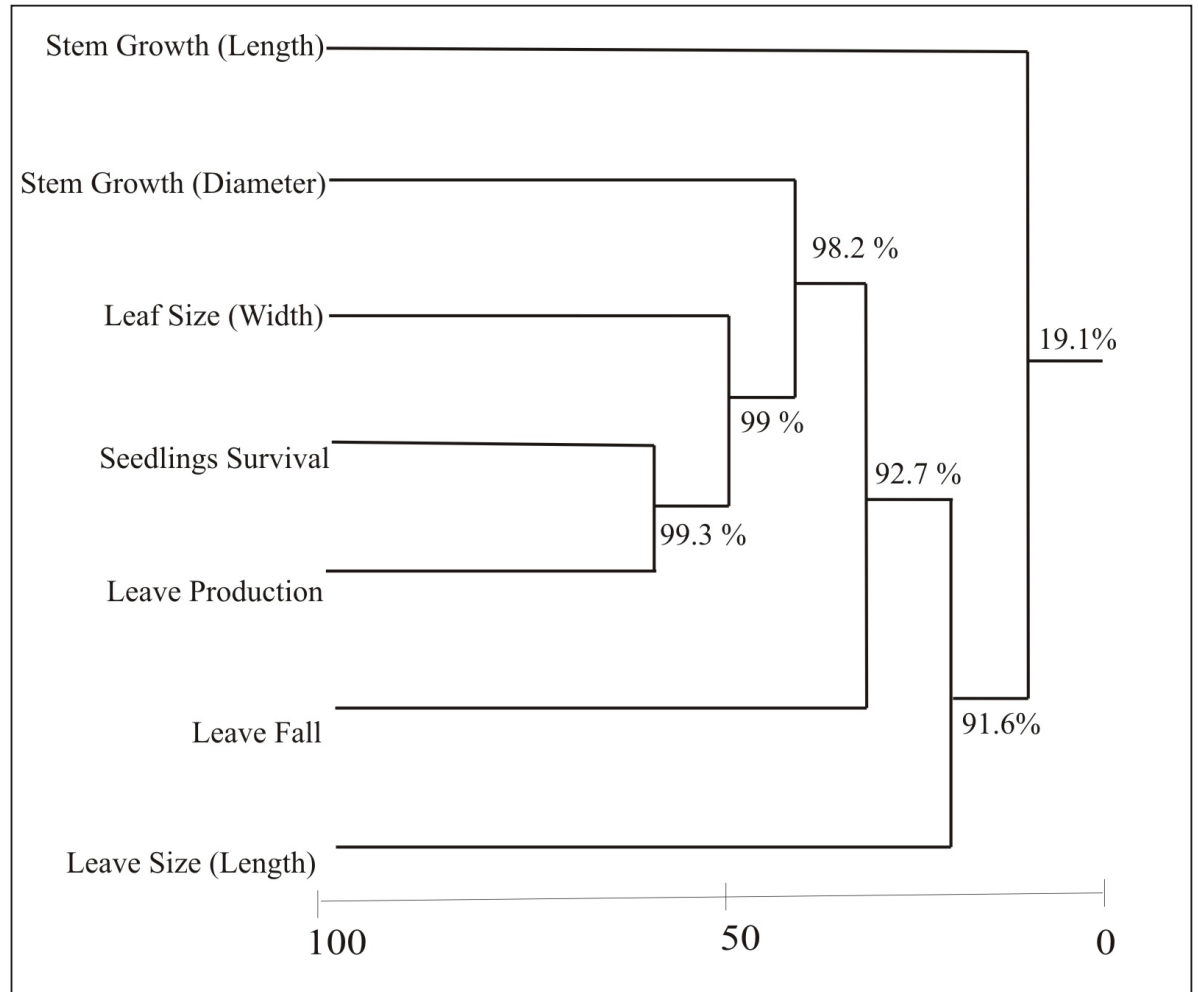

FIGURE 5 - The cluster analysis demonstrating association of growth attributes of seedlings exposed to chronic treatment 
The control response gave rise to 5 cluster groups amongst the seedling growth attributes such as the declining affinity between seedling survival and leaf production (A, 99.1\%), stem diameter and leaf fall $(\mathrm{B}, 98.4 \%)$, leaf width and stem diameter $(\mathrm{C}, 97.9 \%$ with groups $\mathrm{A}$ and $\mathrm{B})$, leaf length and stem diameter (D, 96.1\%), stem diameter and leaf length $(86.1 \%)$, and stem height and stem diameter (E, 22.4\%) in that respective order (Figure 6).

The correspondent analysis for the first and second axes for acute, chronic and control were $98.1 \%$ and $1.1 \%, 93.2 \%$ and $5.95 \%, 93.03 \%$ and $5.17 \%$ respectively (Table-3). The cumulative percentages for acute, chronic and control were $99.16 \%, 99.1 \%$ and $98.2 \%$ respectively (Table-3). The correspondence analysis provided a further insight indicating differences in mangrove seedling response pattern for the different crude oil exposure (acute and chronic treatments) and control (Figures 7 e 8). Seedling survival demonstrated high response pattern for the three series of treatment, while stem height, stem diameter, and leaf production demonstrated moderate response for the 3 treatments (acute, chronic and control), However, leaf length demonstrated high response pattern for control and chronic exposure but moderate for acute exposure. Leaf width shared the same high response pattern for control and chronic but differed with acute that exhibited low response. Similarly leaf fall for the control and chronic exposure had low response, contrary to high response observed for acute exposure.

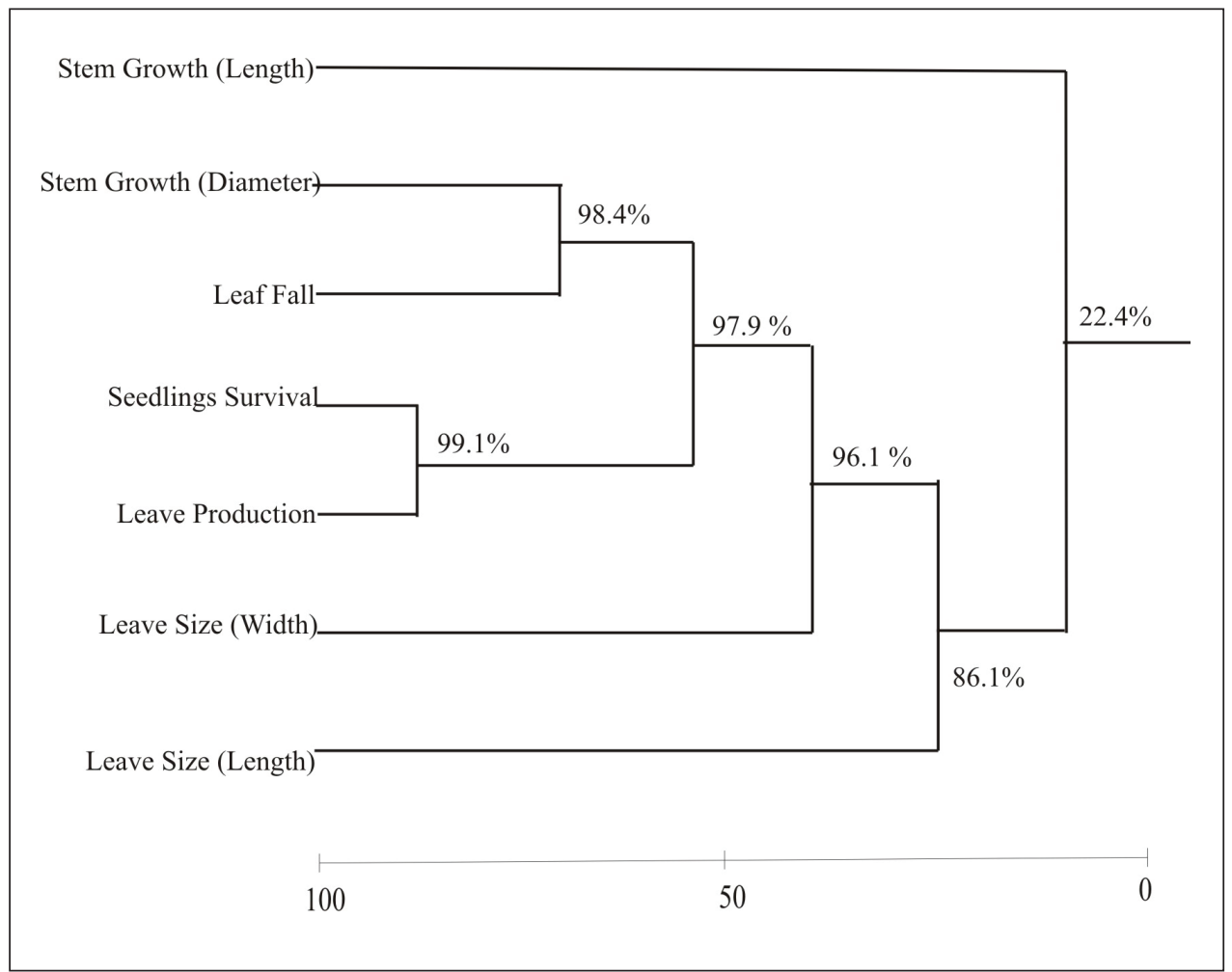

FIGURA 6 - The cluster analysis demonstrating association of growth attributes of seedlings exposed to no treatment

\section{DISCUSSION}

Human development activities cause particular risks for plant habitat, wildlife and human communities that involve intrusion into relatively pristine environmental areas, disrupting sometimes the habitat and facilitating decline in habitat quality and biodiversity loss.
Utilization and dependence on natural resources also may skew the ecobalance and alter inter-relationship among them. Efficiency in resource management options and regeneration, could transform the current declining quality of the ecosystem into one that is healthier, more resilient and productive. The mangrove ecosystem which is more ecologically sensitive to human perturbation 


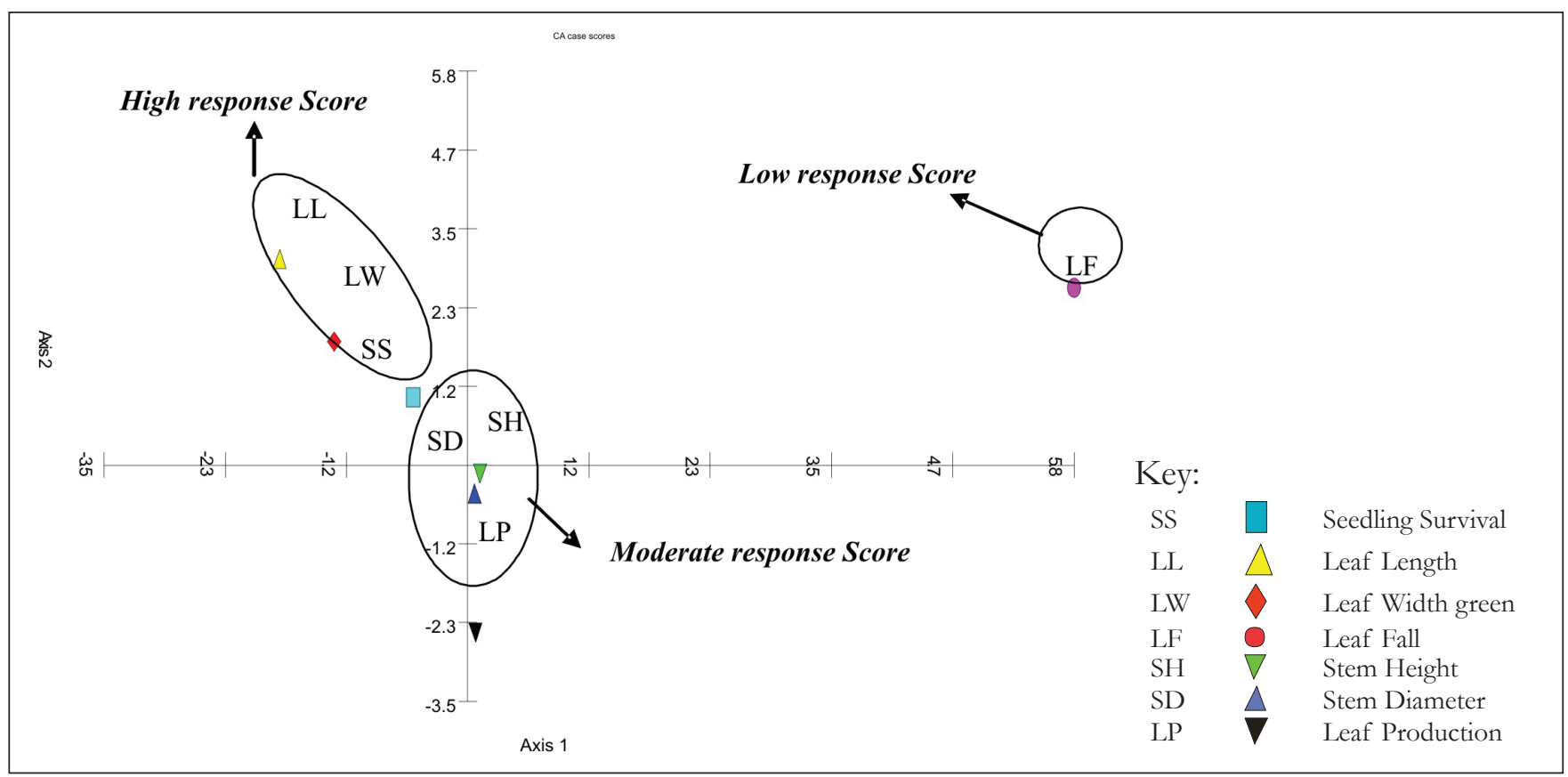

FIGURE 7 - The arch effect (relationship between the first two axes) of the correspondence analysis indicating response of seedling attributes for control

and natural reestablishment processes also demonstrates exceedingly poor potential for rejuvenation of natural vegetation. This peculiar characteristic is further exacerbated by contamination from crude oil spills and other human activities. The rehabilitation of degraded habitats, through replanting exercise requires considerable understanding of the factors associated with the growth processes and seedling survival. This is crucial particularly as it relates to the predominant environmental concern in the region with is presence of elevated hydrocarbon in the environment $(2,17,23)$.

In our study on the different exposure levels (acute and chronic) of crude on mangrove seedling growth responses were demonstrated. Our observations elucidated disparity in mangrove seedling growth response with crude oil treatments (acute and chronic). For instance, the improved or enhanced growth performance for each of the attributes by the control against the treatments is an indication of the obtrusive and interfering role of crude oil on seedling development as demonstrated by comparison (Wilcoxon sign -rank t-test) between treatments (acute and chronic and control) where variation between the two exposure levels were not significant (Wilcoxon sign -rank, t-test $(-7.0)<\mathrm{p}$ $(0.85)_{0.05}$, whereas relationship between control and chronic exposure (Wilcoxon sign - rank, t-test (1.0) $>\mathrm{p}(0.47)_{0.05}$ and that between control and acute (Wilcoxon sign - rank t-test $(1.0)>\mathrm{p}(0.29)_{0.05}$ both demonstrated significant differences. However, the response amongst the treatments projected the mangrove seedlings as having responded better under chronic condition than in acute exposure as demonstrated by the trend observed on stem and leaf growth attributes (Figures 2 and 3). The cluster analysis also grouped similarly the same attributes as having the highest affinity for chronic (between seedling survival and leaf production -99.3\%) treatment (Table 3). And control condition (between seedling survival and leaf production -99.1\%) between seedling survival and leaf production seedling survival and leaf production (Table 3). This relationship is further corroborated by the correspondence analysis with chronic and control having similar responses pattern for high (Leaf size length, Leaf size width and seedling survival), moderate (Stem height, stem diameter, and leaf production) and low (leaf fall). Nonetheless, mangrove seedlings under acute exposure recorded two attributes for high responses (Leaf fall and seedlings survival), four attributes for moderate response (Stem height, stem diameter, Leaf size length and leaf production) and Leaf size width for low response (Figures 7 e 8).

These underscore the fact that acute exposure of seedling had more damaging effect on 


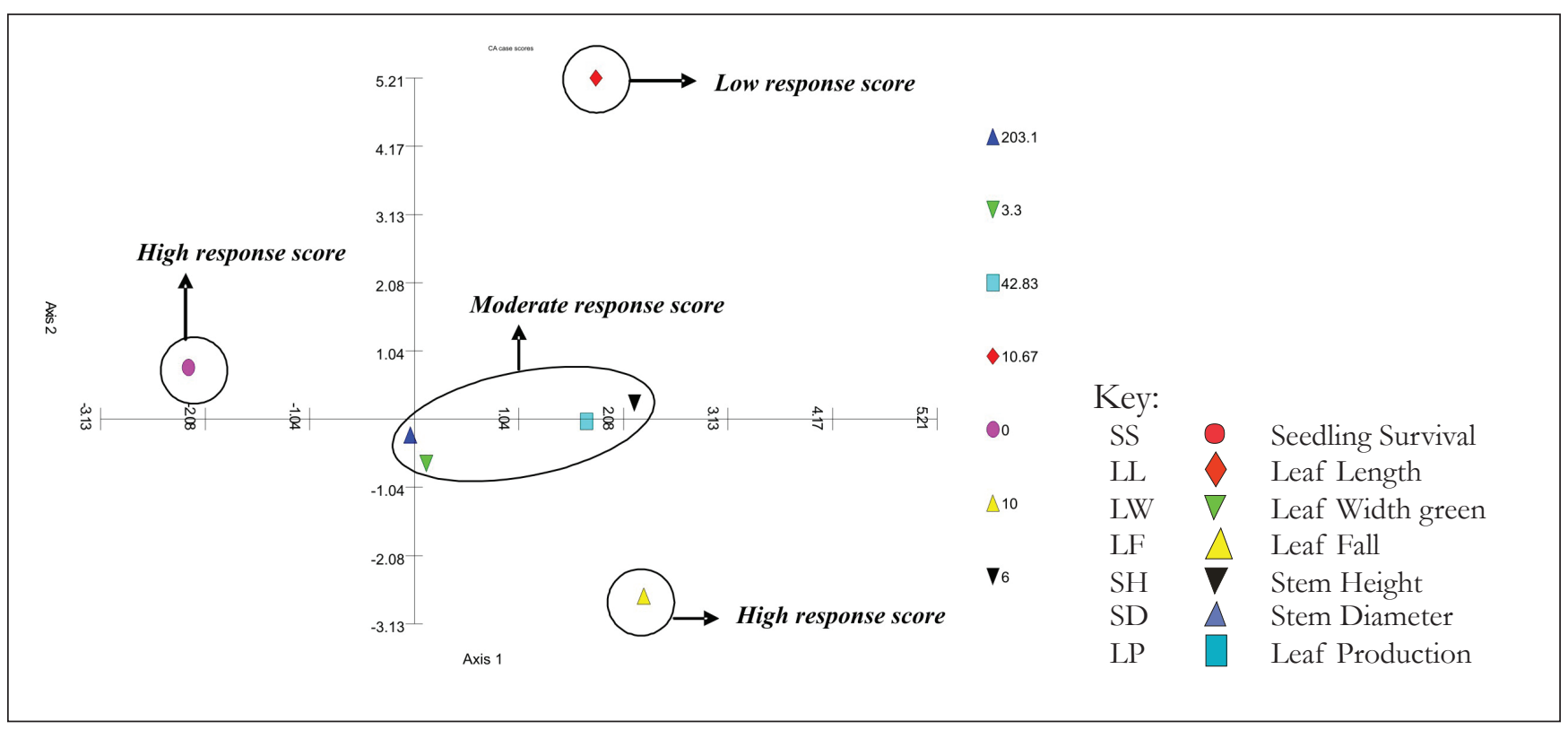

FIGURE 8 - The arch effect of the correspondence analysis indicating response of seedling attributes for acute treatment

seedlings than the chronic exposure. This observation is in consonance with the work of Proffit et al. (24) on mangrove seedlings subjected to different exposure levels (acute and chronic).

Chindah et al. (25) attributed the observed declining growth tendencies to the possible hash and stringent physiological condition imposed by polycyclic aromatic components associated with crude oil. This scenario was also demonstrated for mangrove seedlings under chronic exposure. For instance the development of stem (height and girth) and leaf (length and width) based on the relative growth rate suggests that the acute exposure of seedling had more damaging effect on seedlings than the chronic exposure. Similar observation was made on mangrove seedlings by Proffit et al. (24), at different exposure levels (acute and chronic) and demonstrated linear growth but less than that of the control.

Other analogous studies haveindicated such adverse consequences of the negative crude oil effect on mangrove seedling $(8,9,24,26,27)$. This process may have been achieved by the crude oil altering the sediment quality (properties) firstly; by reducing sediment porosity and gaseous exchange that in turn may have a negative consequences on the physiological function of the plant $(7,28)$. Secondly crude oil may possibly lower mineral - nitrogen by the process of immobilization of mineral-nitrogen by the activities of soil micro-organisms during degradation of crude oil (petroleum hydrocarbons) impacted soil (29) thus making nitrogen unavailable to the plant.
Thirdly, petroleum hydrocarbons induce stress in salt-extracting plants such as the mangroves plant, by disrupting the ability of the roots to exclude ions from sea or brackish waters (29). Oil stress in salt-excluding halophytes, such as Mangroves, results from interference by hydrocarbons in this process (30). Chloride ion exclusion in the roots of Mangrove seedlings is disrupted by exposure to other hydrocarbons such as diesel fuel, and toluene $(31,33,34)$. In effect oil stress in Mangroves is an artificially induced hyper salinity syndrome in which the oil-exposed trees are less able to exclude salt from their root tissues. Thus concentration of sodium, the principal seawater cation, would be elevated in the tissues of Mangrove plants unable to exclude salt efficiently in their roots. Potassium ion, a major physiological cation serves as a reference. In a healthy tree, the ratio of sodium to potassium would be smaller than in a tree unable to exclude salt effectively. The responses in trends provide concrete and imperative contrivance for understanding consequence of crude oil on mangrove seedlings development.

\section{REFERENCES}

1. Ekweozor IKE. A Baseline Study for the Monitoring of Oil Pollution in the Bonny Estuary, Nigeria. M. Phil [thesis]. Nigeria: Rivers State University of Science and Technology, Port Harcourt; 1985. 
2. Niger Delta Environnemental Survey - NDES. Preliminary Report, 1st Phase. 1996;1:1-96.

3. Niger Delta Development Commission - NDDC. Biodiversity of the Niger Delta Environment Niger Delta Development commission master plan Project Final report. Source: Niger-Delta Development commission, 2004.

4. Keay RWJ, Onochie CFA, Standfled, DP. Nigerian tree. Federal Department of Forestry Research. Ibadan: Nigeria: National; 1964.

5. Niger Delta Environnemental Survey - NDES. Ecological Zonaion and Habitat classification. Phase Report. 2000;1:1-66.

6. Research Planning Institute - RPI. Environmental Baseline studies for establishment of Control criteria and standards against petroleum related pollution in Nigeria. Nigeria: Research Planning Institute; 1985. RPI/84/4/15-7.

7. Amadi A, Abbey SD, Nma A. Chronic effect of oil spill on soil properties and microflora of a rainforest ecosystem in Nigeria. Water, Air and Soil Pollutions. 1996;86(1-4):1-11.

8. Baker JM. Impact of the Petroleum Industry on the Mangrove Ecology. In: Proceedings of the Seminar on the Petroleum Industry and the Nigerian Environment. Nigeria: NNPC/FMW \& H, Petroleum Training Institute, Warri; 1981. p. 71-89.

9. Baker JM. Investigation of oil industry influences on tropical marine ecosystems. Marine Pollution Bulletin. 1981;12(1):6-10.

10. Ekweozor IKE, A review of the effect of oil pollution in west african environment. Discovery and Innovation. 1989;1(3) 27-37.

11. Gobo AE. Relationship between rainfall trends and flooding in the Niger Delta - Benue River Basin. J meterology.1988;13(132):220-4.

12. Imevbore AMA. The impact of oil pollution on the biota of the Niger delta. seminar on the environmental aspects of oil pollution in the Niger delta, Nigeria: Port Harcourt; 1979.

13. Imevbore AMA, Adeyemi SA. Environmental monitoring in relation to prevention and control of oil pollution In: Proceedings of the Petroleum Industry and the Nigerian Environment. Nigeria: NNPC/ FMOW \& H Warri; 1981. 135-142.
14. International Petroleum Industry Environmental Conservation - IPIECA. Biological impacts of oil Pollution: Mangroves [online]. 1993 [acesso em 20 jul. 2008]. Disponível em: http://www.ipieca.org.

15. Snowden RJ, Ekweozor IKE. The impact of a minor spillage in the estuarine Niger Delta. Marine Pollution Bulletin. 1987;18(11):595-9.

16. Clarke KR, Gorley RN. Primer Vol. 5: user manual/ tutorial. Plymouth: PRIMER-E; 2001.

17. Nigerian National Petroleum Corporation - NNPC. Petroleum exploration and development in Nigeria. Nigeria: Published by Public Affairs Department; 1985.

18. Hunt R. Plant growth curves. London: Arnold E. Publishers; 1982.

19. Sneath PHA, Sokal RR. Numerical taxonomy. The Principles and Practice of Numerical Classification. San Francisco: W.H. Freeman and Co.; 1973.

20. Clarke KR, Gorley RN. Primer Vol. 6: User manual/ tutorial. Plymouth: PRIMER-E; 2006.

21. SAS JMP version 6.0. SAS Institute Inc., SAS Campus Drive, Cary, North Carolina 27513. USA; 2005.

22. Bray RT, Curtis JT. An ordination of the upland forrest communities of Southern Wisconsin. Ecol. Monogr. 1957;27(4):325-49.

23. Choudhry JK. Sustainable management of coastal development of social needs. The World Forestry Congress Antaly; 13-22 October, 1993. Vol. 6 - topic 1997. 37.

24. Proffitt CE, Devlin DJ, Lindsay M. Effects of oil on mangrove seedlings grown under different environmental conditions. Marine Pollution Bulletin. 1995;30(12):788-793.

25. Chindah AC, Braide SA, Amakiri J, Onokurhefe J. Effects of crude oil on the development of a mangrove seedling (Rhizophora mangle L.) from Niger Delta, Nigeria . Revista Cientifica UDO Agricola. 2007;7(1):181-194.

26. DeLaune RD, Gambrell RP, Pardue JH, Patrick Jr. WH. Fate of petroleum hydrocarbons and toxic organics in louisiana coastal environments. Estuaries and Coasts. 1990;13(1):72-80. 
27. Duarte CM, Geertz-Hansen O, Thampanya U, Terrados J, Fortes MD, Kamp-Nielsen L, et al. Relationship between sediment conditions and mangrove Rhizophora apiculata seedling growth and nutrient status. Mar Ecol Prog Ser. 1998;175:277-83.

28. Institute of Pollution studies - IPS. Environmental data acquisition of some NNPC Operational Area. 1989. RSUST/IPS/TR/89/03.

29. Page DS, E Giliffan S, Foster JC, Hotham JR, Gonzalez L. Mangrove leaf tissue sodium and potassium ion concentrations as sublethal indicators of oil stress in mangrove trees. In: Proceedings of the 1985 Oil Spill Conference. Washington: American Petroleum Institute; 1985. p. 391-3.

30. Scholander PF. How mangroves desalinate water. Physiologia Plantarum. 1968;21:251-61.

31. Teas, HJ. Silviculture with saline water. In: Hollaender A. editor. The biosaline concept. New York: Plenum Publishing Co.; 1979. p. 117-161.

32. DeLaune RD, Patrick Jr, WH, Buresh RJ. Effect of crude oil on a Louisiana Spartina alterniflora salt marsh. Environmental Pollution. 1979;20:21-31

33. Nnyong EE, Anita EE. A Predictive Model of Vulnerability of Oil Spill of Nigerian Coastal Region. In: Proceedings of the Petroleum industry and the Nigerian Environment - NNPC/FHW \& H - 14 Nov 1985. Nigeria: Kaduna; 1987. p. 117-22.

34. Odu CTI. Microbiology of soils contaminated with petroleum. Hydrocarbos. Extent of contamination and some soil and microbial properties affected after contamination. J Institute of Petroleum. 1972;58:201-8.

Recebido: 04/12/2007

Received: 12/04/2007

Aprovado: 08/05/2008

Approved: 05/08/2008 